\title{
ANALISIS LAPORAN KEUANGAN DENGAN MENGGUNAKAN RASIO KEUANGAN UNTUK MENILAI KEMAMPUAN PENYALURAN KREDIT PADA KOPERASI WANITA HINDU DEWI LAKSMI PROVINSI BALI
}

\author{
Ni Kadek Sudarmini ${ }^{1}$ \\ Luh Putu Virra Indah Perdanawati ${ }^{2}$ \\ ${ }^{1,2}$ Fakultas Ekonomi Universitas Ngurah Rai, Bali, Indonesia \\ 1e-mail : kadeksudarmini05@gmail.com
}

\begin{abstract}
ABSTRAK
Koperasi sebagai salah satu lembaga di bidang jasa keuangan, selain berfungsi sebagai penyimpan dana dari masyarakat, juga sebagai penyalur kredit yang berupa pinjaman atau tambahan modal untuk kelancaran usahanya. Dalam menyalurkan kredit koperasi harus memiliki strategi untuk meminimalisir terjadinya kredit macet yang dapat merugikan pihak koperasi. Salah satu dengan melakukan analisis terhadap laporan keuangan dengan menggunakan rasio untuk menilai kemampuan penyaluran kredit koperasi.Tujuan penelitian ini adalah untuk mengetahui apakah Koperasi Wanita Dewi Laksmi Provinsi Bali mampu menyalurkan kredit dengan baik ditinjau dari Cash Ratio, Return On Asset, Loan to Deposit Ratio, dan Non Performing Loan. Teknik analisis data yang digunakan adalah deskriptif kuantitatif dengan menggunakan teknik pengumpulan data seperti observasi, wawancara dan dokumentasi sedangkan jenis data yang digunakan dalam penelitian ini adalah data primer dan data sekunder. Di mana data primer berupa laporan keuangan koperasi seperti neraca dan laporan laba rugi sedangkan data sekunder berupa keterangan langsung dari sumber berupa opini subyek (orang) secara individu atau kelompok.Kesimpulan dari penelitian ini yaitu kemampuan koperasi dalam menyalurkan kredit ditinjau dari Cash Rasio, ROA,LDR serta NPL dalam keadaan baik karena setiap periodenya mengalami peningkatan dan Koperasi Wanita Hindu Dewi Laksmi Mampu Menyalurkan Kredit secara baik dilihat dari peningkatan nilai rasio.
\end{abstract}

Kata kunci : Laporan Keuangan, Rasio Keuangan, Penyaluran Kredit

\begin{abstract}
Cooperatives as one of the institutions in the field of financial services, in addition to functioning as depositors of funds from the public, also as credit channelers in the form of loans or additional capital for the smooth running of their business. In distributing the criteria for cooperatives must have a strategy to minimize the occurrence of bad loans that can harm the cooperative. One of the ways is by analyzing financial statements by using a ratio to assess the ability of cooperative lending.The purpose of this study was to find out whether the Women's Dewi Laksmi Cooperative in Bali Province was able to channel credit well in terms of Cash Ratio, Return On Assets,Loan to Deposit Ratio, and Non Performing Loans. Data analysis techniques used are descriptive quantitative by using data collection techniques such as observation, interviews and documentation while the data types used in this study are primary data and secondary data. Where primary data in the form of cooperative financial statements such as balance sheets and income statements while secondary data in the form of information directly from the source in the form of subject opinions (people) individually or in groups. The conclusion of this study is the ability of cooperatives to channel loans in terms of cash ratios, ROA, LDR and NPLs in good condition because each Keywords: Financial Report, Financial Ratio, Credit Distribution
\end{abstract}




\section{PENDAHULUAN}

Peranan pelaku ekonomi dalam kegiatan usaha di Indonesia sangat penting di dalam sistem keuangan di Indonesia. Para pelaku ekonomi berupaya untuk membangun perekonomian yang turut serta membangun kesejahteraan masyarakat Indonesia. Koperasi merupakan bagian dari perilaku ekonomi yang bertujuan untuk membangun perekonomian masyarakat yang maju, adil dan makmur berlandaskan Pancasila dan UndangUndang Dasar 1945. Dalam kaitannya mempercepat pembangunam perekonomian masyarakat, koperasi memiliki peranan penting dalam perkembangan perekonomian Indonesia ini tertuang dalam Undang-Undang No 25 tahun 1992 tentang perkoperasian. Koperasi diharapkan menjadi pusat pelayanan kegiatan perekonomian di daerah dan dapat memegang peranan utama dalam kegiatan perekonomian sesuai dengan kemampuan serta keadaan daerah setempat yang pada akhirnya mampu berperan sebagai kekuatan dan ketahanan perekonomian nasional berdasarkan prinsip koperasi. Dalam kaitannya mempercepat pengembangan perekonomian masyarakat koperasi memiliki peranan penting untuk meningkatkan kesejahteran ekonomi dan sosial masyarakat melalui penyaluran kredit bagi anggota dan masyarakat maupun para pengusaha kecil.Kredit merupakan suatu pinjaman yang didapatkan anggota atau masyarakat dari pihak koperasi. Penyaluran dana kredit merupakan sumber penghasilan yang sangat besar bagi koperasi yang diperoleh dari bunga, biaya administrasi dan biaya komisi. Disamping itu terdapat biaya tambahan atau denda apabila angsuran melebihi waktu yang ditentukan. Sehubungan dengan itu jumlah pemberian kredit yang akan diterima setiap anggota, masyarakat, maupun pengusaha kecil akan bervariasi yang akan ditentukan dari pos-pos laporan keuangan koperasi, baik yang mencakup rasio keuangan, prinsipprinsip koperasi, serta pertimbangan lain yang dipersyaratkan oleh koperasi. Koperasi Wanita Hindu Dewi Laksmi merupakan salah satu koperasi wanita di Denpasar yang bergerak dalam bidang usaha simpan pinjam yang kegiatan simpan pinjamnya berjalan cukup lancar dimana salah satunya adalah penyaluran kredit. Sama dengan Koperasi Simpan Pinjam lain, Koperasi Wanita Hindu Dewi Laksmi memberikan pinjaman berupa kredit yang sudah dipercaya oleh masyarakat sejak tahun 2013. Hal tersebut dapat dilihat dari jumlah penyaluran kredit yang dilakukan koperasi setiap tahunnya. Yang dapat dilihat pada tabel 1.1 berikut ini : 
Tabel 1

Jumlah kredit yang disalurkan oleh Koperasi Wanita Hindu Dewi Laksmi Tahun 20152017

\begin{tabular}{|l|l|}
\hline Tahun & $\begin{array}{l}\text { Kredit yang disalurkan } \\
(\mathrm{Rp})\end{array}$ \\
\hline 2015 & 202.500 .000 \\
\hline 2016 & 276.000 .000 \\
\hline 2017 & 297.700 .000 \\
\hline Jumlah & 776.200 .000 \\
\hline \multicolumn{2}{|l|}{ Sumber : Koperasi Wanita Hindu Dewi Laksmi Provinsi Bali }
\end{tabular}

Dari dilihat tabel 1 diatas menunjukkan bahwa anggota lebih cenderung mengajukan kredit, hal ini terlihat dari jumlah kredit yang disalurkan koperasi mengalami peningkatan setiap tahunnya. Semakin besarnya jumlah kredit yang disalurkan, maka akan membawa konsekuensi dan risiko yang harus ditanggung oleh koperasi yang bersangkutan. Non Performing Loan (NPL) merupakan rasio yang digunakan untuk mengukur kemampuan koperasi dalam mengcover risiko kegagalan pengembalian kredit oleh anggota ataupun masyarakat.Semakin tinggi tingkat NPL maka semakin besar pula resiko kredit yang ditanggung oleh pihak koperasi. Keberhasilan Koperasi Wanita Hindu Dewi Laksmi dalam menyaluran kredit tidak terlepas dari sumber-sumber permodalan koperasi itu sendiri yang berasal dari modal sendiri (Simpanan Anggota dan Cadangan SHU) serta dari masyarakat luas atau dari lembaga lainnya atau dana pihak ketiga (DPK).
DPK merupakan sumber dana terpenting bagi koperasi dikarenakan hampir 8090\% dana yang dikelola oleh koperasi berasal dari dana pihak ketiga. Serta dalam menyalurkan kredit Koperasi Wanita Hindu Dewi Laksmi memiliki prosedur penyaluran kredit yang dijalankan dalam pengelolaan pemberian kredit kepada anggota. Prosedur penyaluran kredit merupakan ketentuan yang menjamin hak koperasi dalam menyalurkan kredit kepada peminjam dengan kata lain bahwa menyalurkan kredit kepada anggota atau masyarakat mewajibkan untuk melunasi kreditnya sesuai dengan waktu yang disepakati. Seperti badan usaha lain, koperasi memerlukan suatu alat yang dapat memberikan informasi bagi pihak yang berkepentingan pada perkembangan koperasi. Alat yang dimaksud adalah laporan keuangan yang dibuat oleh pihak manajemen, selain digunakan sebagai sumber informasi mengenai perkembangan usaha dapat juga sebagai alat pertanggung jawaban dari pihak 
manajemen koperasi. Dari laporan keuangan koperasi diatas, Koperasi Wanita Hindu Dewi Laksmi perlu mengadakan analisis terhadap laporan keuangan untuk memperoleh gambaran mengenai kemampuan keuangan koperasi dengan menggunakan pedoman penilaian kesehatan koperasi yang ditetapkan oleh Menteri Koperasi dan Usaha Kecil dan Menengah Republik Indonesia yaitu Peraturan Deputi Bidang Pengawasan Kementerian Koperasi dan Usaha Kecil dan Menengah Republik Indonesia Nomor : 06/Per/Dep.6 /IV /2016. Kemampuan keuangan koperasi dapat dipahami dengan melakukan analisis terhadap laporan keuangan koperasi dengan menggunakan alat analisa berupa rasio salah satunya adalah Loan to Deposit Rasio (LDR). LDR digunakan untuk mengukur tingkat likuiditas koperasi, Semakin tinggi rasio ini menunjukan semakin besar DPK yang digunakan untuk menyalurkan kredit, namun disisi lain terlalu tingginya rasio ini juga menimbulkan resiko rendahnya likuiditas koperasi. Koperasi perlu memperhatikan aspek profitabilitas atau tingkat keuntungan yang dimiliki, dalam menjalankan kegiatan operasionalnya. Profitabilitas adalah acuan untuk mengukur laba yang diraih oleh koperasi , laba yang diraih koperasi merupakan refleksi dari kinerja koperasi dalam mengelola dana yang dihimpunnya. Koperasi yang mampu mengahasilkan laba besar berarti koperasi mampu secara efisien menjalankan usahanya. Profitabilitas disini biasanya menggunakan rasio ROA (Return on Asset). Kredit sebagai salah satu sumber pemasukan terbesar bagi koperasi, maka koperasi harus bijak dalam menentukan tingkat suku bunga pendanaan maupun suku bunga simpanan. Tingkat keuntungan yang dihasilkan oleh koperasi terkait dengan keseimbangan jumlah dana yang mampu dihimpun dan jumlah dana yang mampu disalurkan. Informasi dari rasio-rasio secara berkala sangat penting, apalagi untuk usaha yang dijalankan oleh Koperasi Wanita Hindu Dewi Laksmi Provinsi Bali. Dengan rasio keuangan akan terlihat jelas bagaimana indikator keuangan yang dapat memperlihatkan posisi, kondisi keuangan serta kegiatan usaha yang telah dicapai oleh koperasi dalam periode tertentu. Dengan demikian diharapkan hal tersebut dapat berguna bagi para pengambil keputusan untuk mengambil langkah-langkah yang tepat sehingga senantiasa dilakukan analisis rasio keuangan pada koperasi tersebut pada masa yang akan datang. 


\section{METODE PENELITIAN}

\section{Desain Penelitian}

Desain penelitian yang digunakan yang digunakan pada penelitian ini adalah metode kuantitatif dengan jenis penelitian deskriptif dengan mengumpulkan data, disusun, diinterprestasikan, dan dianalisis sehingga memberikan kesimpulan yang jelas dan objektif terhadap masalah yang ada. Adapun teknik analisis data yang digunakan peneliti yaitu dengan menggunakan rasio keuangan yaitu cash rasio, loan to deposit rasio, Return on Asset dan non performing loan untuk menilai kemampuan penyaluran kredit koperasi.

\section{Identifikasi Variabel}

Variabel - variabel yang dapat diidentifikasi dalam penelitian ini adalah

\section{Cash Ratio}

2. Return on Asset (ROA)

\section{Loan to Deposit Ratio (LDR)}

\section{Non Performing Loan}

\section{Definisi Operasional Variabel}

1. Cash Ratio (Rasio Kas), yaitu Rasio ini digunakan untuk mengukur besarnya uang kas yang tersedia untuk melunasi kewajiban jangka pendek yang ditunjukan dari tersedianya dana kas atau setara kas. (Kasmir : 2016).

2. Return on Asset (ROA), yaitu rasio yang mengukur seberapa efisien suatu perusahaan untuk mengelola asetnya untuk menghasilkan laba selama periode tertentu. (Eduardus Tandelilin).

3. Loan to Deposit Ratio (LDR), yaitu rasio perbandingan antara jumlah dana yang disalurkan kemasyarakat (Kredit) dengan jumlah dana masyarakat dan modal sendiri yang digunakan.Kasmir (2012:225)

4. Non Performing Loan (NPL), yaitu rasio yang digunakan untuk mengukur kemampuan koperasi dalam mengcover resiko kegagalan pengembalian kredit.

\section{Jenis Data}

Berdasarkan sumber data, penelitian ini dapat dikelompokkan dalam dua jenis yaitu data primer dan data sekunder yaitu

a. Data Primer

Yaitu data yang berupa keterangan langsung diperoleh oleh peneliti dari koperasi. Baik yang berupa angka-angka maupun keterangan dan dicatat pertama kalinya oleh peneliti.

b. Data Sekunder

Yaitu data yang dikumpulkan penelitin secara langsunga atau data yang diperoleh dari pihak lain yang berhubungan erat dengan penulisan ini.

Berdasarkan sifatnya, data penelitian dapat dibedakan dalam dua jenis yaitu :

a. Data Kuantitatif, yaitu data yang berupa angka - angka yang menunjukkan jumlah atau banyaknya sesuatu yaitu: laporan keuangan 
koperasi (neraca dan laporan laba rugi).

b. Data Kualitatif, yaitu data yang tidak dinyatakan dalam bentuk angka - angka atau keterangan atau informasi yang menggambarkan keadaan koperasi seperti sejarah singkat koperasi, struktur organisasi serta proses transaksi.

\section{Teknik Pengumpulan Data}

a. Observasi

Yaitu Metode pengumpulan data yang dilakukan dengan proses pengamatan dan pencatatan secara sistematis mengenai gejala-gejala yang diteliti.

b.Metode Wawancara

Yaitu metode pengumpulan data yang dilakukan dengan wawancara atau tanya jawab dengan pimpinan atau staf karyawan yang berhubungan dengan data penelitian yang diberikan wewenang untuk memberikan data yang diperlukan.

c. Metode Dokumentasi

Yaitu pengumpulan data yang dilakukan dengan mempelajari dokumen atau

\section{HASIL DAN PEMBAHASAN}

Analisis Data dan Pembahasan

Analisis Cash Rasio

Analisis ini digunakan untuk mengukur besarnya uang kas yang tersedia untuk melunasi kewajiban jangka pendek yang arsip-arsip dari koperasi ataupun datadata yang berkaitan dengan penelitian.

\section{Teknik Analisis Data}

a. Kuantitatif

Teknik analisis data yang digunakan dalam penelitian ini adalah sebagai berikut :

1. Cash Ratio

$$
\text { Cash }=\frac{\text { Kas koperasi }}{\text { Hutang lancar }} \times 100 \%
$$

2. Return on Asset (ROA)

Return on asset

$$
=\frac{\text { Laba bersih }}{\text { Total aktiva }} \times 100 \%
$$

3. Loan to Deposit Ratio (LDR)

$$
\begin{aligned}
& L D R \\
& =\frac{\text { Kredit yang disalurkan }}{\text { Dana yang diterima }} \times 100 \%
\end{aligned}
$$

4. Non Performing Loan (NPL)

$$
N P L=\frac{\text { Pinjaman bermasalah }}{\text { total pinjaman }} \times 100
$$

ditunjukan dari tersedianya dana kas atau setara kas. Maka perhitungan Cash Ratio dalam penelitian ini disajikan pada tabel 1 sebagai berikut : 
Tabel 2

Perhitungan Cash Ratio dari Tahun 2015-2017 Koperasi Wanita Hindu Dewi Laksmi Provinsi Bali

\begin{tabular}{|c|c|c|c|c|}
\hline No & Tahun & $\begin{array}{c}\text { Kas+Bank } \\
\text { (Rp) }\end{array}$ & $\begin{array}{c}\text { Hutang } \\
\text { Lancar } \\
\text { (Rp) }\end{array}$ & $\begin{array}{c}\text { Cash Rasio } \\
(\%)\end{array}$ \\
\hline 1 & 2015 & 134.956 .671 & 48.512 .338 & 278.19 \\
\hline 2 & 2016 & 197.524 .972 & 125.583 .866 & 157.29 \\
\hline 3 & 2017 & 240.130 .074 & 63.107 .467 & 380.51 \\
\hline \multicolumn{2}{|c|}{ Jumlah } & 572.611 .717 & 237.203 .671 & 815.99 \\
\hline \multicolumn{2}{|c|}{ Rata-rata } & 190.870 .572 & 79.067 .890 & 271,99 \\
\hline
\end{tabular}

Sumber: Pengolahan Data Penelitian Pada Lampiran

Berdasarkan tabel diatas maka diperoleh pembahasan sebagai berikut :

- Tahun 2015, cash ratio sebesar $278,19 \%$ artinya setiap Rp. 100 hutang lancar akan dijamin oleh kas dan bank sebesar Rp. 278,19 dari kas dan bank yang tersedia.

- Tahun 2016, cash ratio sebesar $157,29 \%$ artinya setiap Rp.100 hutang lancar akan dijamin oleh kas dan bank sebesar Rp 157,29 dari kas dan bank yang tersedia. Tahun 2017, cash ratio sebesar $380,51 \%$ artinya setiap Rp 100 hutang lancar akan dijamin oleh kas dan bank sebesar Rp, 380,51.kas dan bank yang tersedia. Terjadinya penurunan cash rasio pada tahun 2016 disebabkan karena kas dan bank yang dikuasai turun sebesar

$20,9 \%$, dan kenaikan cash rasio disebabkan karena kas dan bank yang dikuasai naik sebesar $223.22 \%$.
Jadi dapat disimpulkan bahwa cash ratio Koperasi Wanita Hindu Dewi Laksmi pada tahun 2015-2017 adalah likuid dan berada pada posisi yang cukup baik sesuai dengan standar yang ditetapkan Permenkop-UKM RI 2006 yaitu $\geq 200 \%$ karena koperasi mampu memenuhi kewajiban finansialnya walaupun pada tahun 2016 mengalami penurunan dan dinilai masih mampu dalam penyaluran kredit.

\section{Analisis Return On Asset (ROA)}

Return on Asset yaitu rasio yang digunakan untuk mengukur seberapa efisien suatu perusahaan untuk mengelola asetnya untuk menghasilkan laba selama periode tertentu. Maka perhitungan Return On Asset (ROA) dalam penelitian ini disajikan pada tabel 2 sebagai berikut : 
Analisis Laporan Keuangan Dengan menggunakan Rasio Keuangan Untuk Menilai Kemampuan Penyaluran Kredit Pada Koperasi Wanita Hindu Dewi Laksmi Provinsi Bali

Tabel 3

Perhitungan Return On Asset dari Tahun 2015-2017 Koperasi Wanita Hindu Dewi Laksmi Provinsi Bali

\begin{tabular}{|c|c|c|c|c|}
\hline No & Tahun & $\begin{array}{c}\text { Laba Sebelum } \\
\text { Pajak }\end{array}$ & $\begin{array}{c}\text { Total Aktiva } \\
(\mathrm{Rp})\end{array}$ & ROA \\
\hline 1 & 2015 & 20.342 .639 & 324.966 .671 & $6,26 \%$ \\
\hline 2 & 2016 & $27.877,900$ & 421.567 .172 & $6,61 \%$ \\
\hline 3 & 2017 & $32,060,842$ & 318.722 .275 & $10.06 \%$ \\
\hline \multicolumn{2}{|l|}{ Jumlah } & 80.281 .381 & 1.065 .256 .118 & $22.93 \%$ \\
\hline \multicolumn{2}{|l|}{ Rata-rata } & 26.760 .460 & 355.085 .372 & $7.64 \%$ \\
\hline
\end{tabular}

Sumber : Koperasi Wanita Hindu Dewi Laksmi Provinsi Bali

Dari tabel diatas dapat disimpulkan ROA Koperasi Wanita Hindu Dewi Laksmi Provinsi Bali per 31 Desember 2015 sebesar 6,26\% yang berarti setiap Rp. 100 aset menghasilkan keuntungan Rp. 6,26. Tahun 2016 sebesar 6,61\% yang berarti setiap Rp. 100 aset menghasilkan keuntungan Rp. 6,61. dan Tahun 2017 sebesar 10,06\% yang artinya setiap Rp. 100 aset menghasilkan keuntungan Rp. 10,06. Dari hasil data tersebut dapat diketahui keadaan keuangan koperasi pada tahun 2015-2017 untuk ROA rata-rata keseluruhan mencapai $7.64 \%$ rata-rata ini termasuk kriteria yang baik sesuai dengan Peraturan Perdep M.UKM N0. $6 / 2016$

Alasan dipilihnya ROA sebagai salah satu teknik analisis, karena ROA merupakan rasio yang digunakan untuk mengukur efisiensi penggunaan modal yang dipakai. ROA adalah perbandingan rasio laba sebelum pajak selama 12 bulan terakhir terhadap total aktiva dalam periode yang sama. ROA yang besar menunjukkan koperasi semakin baik dalam mengelola asetnya karena semakin baiknya pengelolaan aset koperasi maka semakin besar pula laba yang dihasilkan koperasi. Oleh karena itu ROA merupakan rasio yang tepat digunakan untuk mengukur efektifitas koperasi dalam menghasilkan keuntungan/laba.

\section{Hubungan ROA terhadap Kemampuan Penyaluran Kredit Koperasi}

ROA yang tinggi menunjukkan koperasi telah menyalurkan kreditnya dengan baik hal ini dapat dilihat dari perolehan bunga pinjaman dan mampu memperoleh pendapatan. Jika nilai ROA tinggi maka koperasi menggunakan aktivanya secara optimal. 


\section{Analisis Loan to Deposit Ratio}

Loan to Deposit Ratio digunakan untuk mengukur perbandingan jumlah dana yang disalurkan dengan jumlah dana masyarakat dan modal sendiri yang digunakan. Maka perhitungan LDR dalam penelitian ini disajikan pada tabel 3 sebagai berikut :

Tabel 3

Perhitungan Loan to Deposit Ratio dari Tahun 2015-2017 Koperasi Wanita Hindu Dewi Laksmi Provinsi Bali

\begin{tabular}{|c|c|c|c|c|}
\hline $\begin{array}{l}\mathrm{N} \\
\mathrm{o}\end{array}$ & Tahun & $\begin{array}{c}\text { Kredit yang } \\
\text { disalurkan } \\
\text { (Rp.) }\end{array}$ & $\begin{array}{c}\text { Dana yang } \\
\text { diterima } \\
\text { (Rp.) }\end{array}$ & $\begin{array}{l}\text { LDR } \\
(\%)\end{array}$ \\
\hline 1 & 2015 & 202.500 .000 & 276.454 .333 & 73,25 \\
\hline 2 & 2016 & 276.000 .000 & 295.963 .306 & 93,25 \\
\hline 3 & 2017 & 297.700 .000 & 318.614 .808 & 93,43 \\
\hline \multicolumn{2}{|c|}{ Jumlah } & 776.200 .000 & 891.032 .447 & 259,93 \\
\hline \multicolumn{2}{|c|}{ Rata- Rata } & 258.733 .333 & 297.010 .815 & 86,64 \\
\hline
\end{tabular}

Dari hasil perhitungan tabel 3 diatas dapat dilihat hasil LDR yang Pada tahun 2015 nilai rasio LDR sebesar $73.25 \%$, nilai ini dapat diinterprestasikan bahwa untuk Rp.100 dana yang diterima koperasi mampu untuk menyalurkan kembali pada anggota dalam bentuk kredit sebesar Rp. 73.25. pada tahun 2016 diperoleh LDR sebesar 93.25 yang berarti setiap Rp.100 dana yang diterima koperasi mampu menyalurkan kembali kepada anggota dalam bentuk kredit sebesar Rp. 93.25. nilai rasio dari tahun 2016 mengalami kenaikan sebesar $20.01 \%$ dari rasio sebelumnya. Hal ini disebabkan karena adanya kenaikan pada kredit. Sedangkan pada tahun 2017 nilai LDR sebesar $93.43 \%$ yang berarti setiap Rp.100 dana yang diterima koperasi mampu untuk menyalurkan kembali dalam bentuk kredit kepada anggota sebesar Rp. 93.42. nilai kredit tahun 2017 mengalami kenaikan sebesar $0.18 \%$. rata-rata LDR dari tahun 20152017 sebesar $86.64 \%$. rata-rata LDR tersebut termasuk dalam kriteria yang baik sesuai dengan ketetapan standar Perhitungan Loan To Deposit Ratio menurut PerDep Bidang Pengawasan M.KUKM RI Nomor : 06/Per/Dep.6/IV/2016 yaitu LDR 80\% $-90 \%$.

Kenaikan rasio LDR menunjukkan bahwa pada setiap tahun terjadi kenaikan jumlah kredit yang disalurkan dengan diimbangi kenaikan jumlah dana yang diterima oleh koperasi. Hal ini menunjukkan semakin besarnya kepercayaan anggota dan masyarakat terhadap koperasi Wanita Hindu Dewi Laksmi. 


\section{Hubungan LDR terhadap Kemampuan Penyaluran Kredit Koperasi}

Penyaluran kredit adalah aktivitas koperasi yang paling utama dalam menghasilkan keuntungan.oleh karena itu sumber pendapatan utama koperasi berasal dari kegiatan ini. Semakin besarnya penyaluran dana dalam bentuk kredit dibandingkan dengan deposit atau simpanan masyarakat pada suatu koperasi membawa konsekuensi semakin besarnya risiko yang harus ditanggung oleh koperasi yang bersangkutan. rasio LDR merupakan rasio perbandingan antara jumlah dana yang disalurkan ke masyarakat (kredit) dengan jumlah dana masyarakat dan modal sendiri yang
digunakan.Rasio ini menggambarkan kemampuan bank membayar kembali penarikan yang dilakukan nasabah deposan dengan mengandalkan kredit yang diberikan sebagai sumber likuiditasnya. Semakin tinggi rasio ini semakin rendah pula kemampuan likuiditas koperasi.

\section{Analisis Non Performing Loan}

Non Performing Loan adalah rasio yang digunakan untuk mengukur kemampuan koperasi dalam mengcover resiko kegagalan pengembalian kredit. Maka perhitungan NPL dalam penelitian ini disajikan pada tabel 4 sebagai berikut

Tabel 4

Perhitungan NPL dari Tahun 2015- 2017 Koperasi Wanita Hindu Dewi LaksmiProvinsi Bali

\begin{tabular}{|c|c|c|c|c|}
\hline No & Tahun & $\begin{array}{c}\text { Kredit yang } \\
\text { diberikan } \\
\text { (Rp) }\end{array}$ & $\begin{array}{c}\text { Kredit } \\
\text { Bermasalah } \\
\text { (Rp) }\end{array}$ & $\begin{array}{l}\text { NPL } \\
(\%)\end{array}$ \\
\hline 1 & 2015 & 202.500 .000 & 12.000 .000 & 5,93 \\
\hline 2 & 2016 & 276.000 .000 & 0 & 0,0 \\
\hline 3 & 2017 & 297.700 .000 & 10.000 .000 & 3,36 \\
\hline & Jumlah & 776.200 .000 & 22.000 .000 & 9,29 \\
\hline Rata & & 258.733 .333 & 7.333 .333 & 3,10 \\
\hline
\end{tabular}

Sumber : Koperasi Wanita Hindu Dewi Laksmi Provinsi Bali 
Berdasarkan tabel NPL pada Koperasi Wanita Hindu Dewi Laksmi Provinsi Bali selama tahun 2015 sampai tahun 2017, maka dapat disimpulkan kondisi NPL sebagai berikut :

1. Secara keseluruhan NPL pada Koperasi Wanita Hindu Dewi Laksmi Provinsi Bali pada posisi yang cukup baik yaitu sesuai yang diajukan oleh Permenkop-UKM RI 2016 pada posisi kurang dari $5 \%$.

2. Terdapat posisi NPL yang kurang baik yaitu pada tahun 2015 yaitu $5,93 \%$, dimana posisi NPL lebih besar dari $5 \%$.

3. Skor tertinggi berdasarkan pedoman penilaian adalah 5,00 apabila nilai rasio 0\% dan Koperasi memperoleh skor 4.00 dengan nilai rasio berada dalam rentang $0 \%$ sampai $\leq 10 \%$.

NPL mencerminkan juga resiko kredit, semakin tinggi tingkat NPL maka semakin besar pula resiko kredit yang ditanggung pihak koperasi. Penyebab terjadinya kredit bermasalah atau tingginya NPL disebabkan karena pihak koperasi kurang teliti dalam melakukan analisinya sehingga apa yang hasusnya terjadi tidak diprediksi sebelumnya. Atau adanya unsur kesengajaan dari peminjam untuk tidak bermaksud membayar kewajibannya kepada koperasi dalam arti peminjam melarikan diri atau tidak adanya itikad baik, dan adanya unsur kesengajaan dari peminjam artinya peminjam mau membayar akan tetapi tidak mampu untuk membayar atau usaha yang dikelolanya telah bangkrut.

$\begin{array}{lcr}\text { Hubungan } & \text { NPL } & \text { terhadap } \\ \text { Kemampuan } & \text { Penyaluran } & \text { Kredit } \\ \text { Koperasi } & & \end{array}$

Non Performing Loan (NPL) adalah rasio yang digunakan untuk mengukur kemampuan koperasi dalam menyalurkan kredit. Semakin besarnya NPL maka semakin buruk kualitas koperasi yang akan menyebabkan kerugian dan semakin renda hnya likuiditas. Secara teori semakin tinggi nilai NPL maka akan menurunkan likuiditas koperasi karena semakin tingginya kredit macet, begitu juga sebaliknya semakin menurunnya NPL maka akan menaikkan likuiditas koperasi yang diperoleh dari bunga pinjaman.

\section{PENUTUP \\ KESIMPULAN}

Dari keseluruhan hasil perhitungan yang ada dapat ditarik kesimpulan bahwa Kemampuan Penyaluran Kredit Koperasi Wanita Hindu Dewi Laksmi Provinsi Bali bila dilihat dari cash rasio sudah baik. Walaupun mengalami penurunan yang disebabkan oleh penurunan nominal penyimpanan di koperasi sehingga menyebabkan penurunan hasil penjumlahan kas dan bank. Tetapi koperasi tetap dikatakan baik karena masih melebihi standar normal yang telah ditetapkan koperasi dimana standar normalnya adalah $125 \%$. Dengan demikian koperasi wanita bisa dikatakan likuid karena koperasi mampu memenuhi kewajiban finansialnya. 
Sedangkan Return on Asset pada Koperasi Wanita Hindu Dewi Laksmi pada tahun 2015 sebesar 6,26\%, pada tahun 2016 sebesar 6,61\% dan pada tahun 2017 sebesar 10,06\% dengan ratarata sebesar 7,64\%. Dengan demikian dapat disimpulkan ROA baik sesuai dengan Peraturan Menteri Koperasi (Perdep M.UKM No. 6/2016. Kenaikan rasio ini menunjukkan semakin baiknya pengelolaan aset koperasi dalam menghasilkan laba. Semakin besar ROA yang diperoleh makan semakin besar pula laba yang dihasilkan oleh koperasi. Sedangkan Loan to Deposit Ratio tahun 2015 sebesar 73.25\%, tahun 2016 sebesar 93.25\% dan tahun 2017 sebesar $93.43 \%$ dengan rata-rata $86.64 \%$ dapat disimpulkan LDR Koperasi Wanita Hindu Dewi Laksmi Provinsi Bali dalam keadaan baik.

Dan terakhir NPL pada tahun 2015 sebesar 5,93\% , tahun 2016 sebesar 0,0\% dan tahun 2017 sebesar 3,36\% dengan rata-rata $3,10 \%$ dapat dikatakan NPL Koperasi Wanita Hindu Dewi Laksmi Provinsi Bali pada posisi yang cukup baik yaitu sesuai yang diajukan oleh Permenkop-UKM RI 2016 pada posisi kurang dari 5\%. Jadi dapat disimpulkan dari nilai Cash Rasio,,Return On Asset,Loan to Deposit Rasio dan Non Performing LoanKoperasi Wanita Hindu Dewi Laksmi Provinsi Bali mampu dalam menyalurkan kredit kepada anggotanya maupun masyarakat dengan baik karena pada setiap periodenya mengalami peningkatan.

\section{SARAN-SARAN}

Berdasarkan hasil simpulan diatas maka saran yang dapat disampaikan dalam kaitannya dengan kemampuan penyaluran kredit Koperasi Wanita Hindu Dewi Laksmi Provinsi Bali adalah

Dilihat dari nilai cash rasio yang dimiliki koperasi mengalami peningkatan dan penurunan, maka hendaknya diperbaiki dengan meningkatkan jumlah kas dan menurunkan hutang lancar.

Untuk menekankan terjadinya kredit bermasalah maka pihak koperasi harus lebih teliti dan selektif lagi melakukan analisisnya dalam memberikan pinjaman dan mencari tahu kemampuan anggota baik dari prospek usaha.watak serta jaminan yang digunakan sehingga Non Performing Loan semakin baik dari tahun ke tahun.

Mengingat persaingan yang semakin ketat dalam perkembangan perkoperasian, maka hendaknya koperasi wanita hindu dewi laksmi provinsi bali dapat meningkatkan perannya dalam memenuhi kebutuhan anggota atau calon anggota, paling tidak mempertahankan kondisi yang dicapai sekarang dan sedapat mungkin kesehatannya lebih ditingkatkan untuk tahun-tahun mendatang. 


\section{DAFTAR PUSTAKA}

Agus Harjito, Hartono. 2008. Manajemen Keuangan. Edisi I. Jakarta : Salemba 4

Abdul Halim dan Muhammad Syam Kusufi.2007. Akutansi Keuangan Daerah.

Edisi 4.Jakarta: Salemba Empat.

Ambarwati, Endang. 2016. Analisis Kinerja Keuangan Menggunakan Rasio Likuiditas pada Bumdes Makmur Sejahtera Desa Kepenuhan Raya Tahun 20112015. Jurnal Fakultas Ekonomi, Universitas Pasir Pengairan.

Chaniago, Arifinal.2001.Ekonomi dan Koperasi. Bandung: CV Rosda Bandung

Fahmi, Irham.2014. Pengantar Perbankan Teori dan Aplikasi.Bandung: Alfabeta.

Harapap, Sofyan Syafri.2008. Analisis Kritis atas Laporan Keuangan. Jakarta: PT Raja Grafindo Persada.

Hasihibuan, Melayu S.P. 2009. Manajemen :Dasar, Pengertian, dan Masalah. Edisi Revisi.jakarta: Bumi Aksara

Ismail. 2010. Manajemen Perbankan.Edisi Pertama.Jakarta: Kencana.

Kasmir. 2016. Manajemen Perbankan. Jakarta: PT Raja Grafindo Persada.

\footnotetext{
— . 2012. Pengantar Manajemen Keuangan. Jakarta: Kencana Prenada Media Group
}

Kementerian Negara Koperasi dan Usaha Kecil Menengah Republik Indonesia. 2006. Peraturan Menteri Negara Koperasi dan Usaha Kecil dan Menengah Republik Indonesia Nomor : 06/Per/M.KUKM/V/2006 tentang Pedoman Penilaian Koperasi Berprestasi. Jakarta: Kementerian KUKM RI

Kementerian Negara Koperasi dan Usaha Kecil Menengah Republik Indonesia. (2016). Peraturan Deputi Bidang Pengawasan Kementerian Koperasi dan Usaha Kecil dan Menengah Republik Indonesia Nomor : 06/Per/Dep.6 /IV $/ 2016$ tentang Pedoman Penilaian Kesehatan Koperasi. Jakarta. Kementerian KUKM RI.

Masrunsyah, Ade Putri. 2018. Analisis Penyaluran Kredit Pada Perbankan Indonesia Ditinjau Dari Rasio Keuangan. Jurnal Ekonomi.

Prastowo,Dwi. 2011. Analisis Laporan keuangan.jakarta : Salemba Empat

Prasnanugraha.2007. Analisis Pengaruh Rasio- Rasio Keuangan Terhadap kinerja Bank Umum DI Indonesia. Tesis Program Studi Magister Sains Akutansi Program Pascasarjana Universitas diponogoro semarang.

Rimbano Dheo, Siti Masitoh. 2016. Analisis Laporan Keuangan Untuk Menilai Kinerja Keuangan Ditinjau Dari Rasio Keuangan Pada Koperasi Produsen Tahu Tempe Indonesia (PRIMKOPTI) 
Analisis Laporan Keuangan Dengan menggunakan Rasio Keuangan Untuk Menilai Kemampuan Penyaluran Kredit Pada Koperasi Wanita Hindu Dewi Laksmi Provinsi Bali

Mura Lubuklingau Tahun 20102014. Adminika Volume 2.

Sartono, R.Agus 2008.Manajemen Keuangan.Yogjakarta: BPFE Universitas Gajah Mada.

S, Munawir. 2004. Analisa Laporan Keuangan. Yogyakarta: Liberty.

Solikin, Agus. 2017. Analisis Rasio Keuangan Untuk Mengukur Kemampuan Pemberian Kredit Pada Nasabah Di PT. BPR Grogol joyo Sukoharjo. Jurnal Pariwisata Indonesia.

Sudana, I Made. 2011. Manjemen Keuangan Perusahaan: Teori dan Praktek. Jakarta. Erlangga
Sugiono. 2016. Metode Penelitian Kuantitatif, Kualitataif dan $R \& D$. Bandung :Alfabeta.

Terry, George dan Leslie W.Rue.2010. Dasar-Dasar Manajemen.Jakarta:PT Bumi Aksara

Tandelilin, Erduardus.2010. Portofolio dan Investasi Teori dan Aplikasi.Edisi Pertama. Yogjakarta: Kanisius Undang-Undang Koperasi No. 25 Tahun 1992. Jakarta 